\title{
Economic Analysis, Egg Quality Characteristics and Growth Parameters of Pullets Fed Graded Levels of Recycled Vegetable Wastes
}

\author{
Vitus Izuazu Uche D.E. Ogbuokiri Chijioke C. Olueze Chinwe M. Nwogu \\ Department of Animal Production and Health Technology, Imo State Polytechnic Umuagwo, Ohaji, Owerri, Nigeria \\ Callistus C. Eke \\ Department of Arts Education, University of Nigeria, Nsukka, Nigeria \\ Colman Ibe \\ Department of Science Laboratory Technology, Imo State Polytechnic, Umuagwo, PMB 1472, Ohaji, Owerri, Nigeria \\ Corresponding author: samdoles@yahoo.com \\ $+2348023098848$
}

\begin{abstract}
A feeding trial was conducted to evaluate the economic analysis, egg quality characteristics and growth parameters of pullets fed graded levels of recycled vegetable wastes. Sixty (60) Shika Brown pullets of 22 week - old were used for the experiment. The sixty pullets were selected from a pool of eighty (80) pullets and were randomly assigned to five (5) treatments with twelve (12) birds per treatment in a Completely Randomized Design (CRD) on the basis of vigor. Each treatment group was further replicated 4 times with three (3) birds per replicate and housed in $2 \mathrm{~m} \times 3 \mathrm{~m}$ pen on a deep litter and fed water and feed ad libitum starting from 7.00 am daily for the twenty- one (21) days of the feeding trial. Five experimental diets were prepared to contain 1.0, 1.5, 2.0 and 2.5\% of the homogenized vegetable meal (HVM), for treatment 1, 2, 3, 4 and 5, respectively. Treatment 1 served as control. The percentage hen-day egg production, albumen index, average feed intake, shell thickness, and yolk color index for all treatments were not significant ( $\mathrm{p}>0.05$ ). Average weight (g), Haugh unit, Yolk index and Feed conversion ratio $(\mathrm{FCR})$ shows that treatments 4 and 5 were significantly better $(\mathrm{p}<0.05)$ than in treatments 1 to 3 . Birds on treatments 4 and 5 converted feed most effectively into an egg $(\mathrm{p}<0.05)$. Feed cost $/ \mathrm{kg}$ bag for treatments 3,4 and 5 were significant $(\mathrm{p}<0.05)$ and more economical than treatments 1 and 2 . Feed used $(\mathrm{kg})$ to produce the $\mathrm{kg}$ of egg were significantly better $(\mathrm{p}<0.05)$ in treatments 4 and 5 than the rest of the treatments, with the control diet numerically poorer $(2.00 \mathrm{~kg}$ fee $/ \mathrm{kg}$ egg produced). The cost of feed $/ \mathrm{kg}$ egg decreased with an increase in the inclusion rate. Treatments $2,3,4$ and 5 were significantly less expensive $(\mathrm{p}<0.05)$ than treatment 1.
\end{abstract}

Keywords: economic analysis, egg quality, recycled vegetables, pullets, performance

\section{Introduction}

Vegetable leaves are seldom added routinely to commercial poultry diets probably because more research is necessary to characterize these feedstuffs as to their digestibility, amino acid profile, and contents of anti-nutritional factors. However, excluding vegetable leaves from commercial poultry feed defeats the benefits arising from its cost reduction advantages and attendant savings accruing to farmers since they are cheaper in terms of affordability than the conventional feed ingredients and can indeed add value to finished feed. Vegetables are rich in essential amino acids, vitamins, minerals, enzymes and antioxidants (Omenka and Anyasor, 2010). Leafy vegetables not only supply minerals, protein, and vitamins which complement the inadequacies of most feedstuffs, they have been reported to be rich in carotenoids (Esonu et al, 2002). Leaf meals are sources of proteins, vitamins, minerals, and oxycarotenoids, which confer yellow color to broiler skin and egg yolk (D'mello et al., 1987 and 1989) and extend the shelf life of broiler meat (Ogbuokiri, 2011). According to McKee 2012, egg yolk has beautiful yellow hue to its xanthophyll content lending baked goods richness in terms of color, which contributes to perceived quality and freshness. The use of solely conventional feed ingredients like maize and soya beans in compounding poultry feed has proved very expensive and has equally reduced the profit margins of farmers making some of them invest in other profitable ventures other than poultry. This is more common with farmers that took bank loans as the cost of money (interest) becomes a burden since they cannot break even and post a moderate profit to keep them in business. To reverse this ugly trend, exploiting the potentials of non-conventional feed ingredients like green vegetable leaves that are most times wasted to improve the protein margin (Odunsi, et al, 1999, Mnereole, 2009, Omenka and Anyasor, 2010 and Ebenebe, et.al, 2011, Ogbuokiri, 2012, Ogbuokiri, et al 2014) is a welcome development. The profit margin in poultry production depends mainly on the feed utilization, day-old chicks cost and efficient management of resources (Nworgu and Egbunike, 2000).

In Cameroon, two major agricultural by-products, cocoa pod husks and mango kernels, i.e. crop residues usually wasted, have been tested in trials with broilers (Teguia 1995; Teguia and Beynen, 2004; Teguia et al 2004). Leaves and forages traditionally used for other purposes or even wasted have also been tested, namely 
sweet potato leaves, bitter leaves, perennial peanuts, and Desmodium spp. (Teguia et al 1993; Teguia et al 2002a). In the various studies, the researchers noted that the dietary maize component was replaced on a weight basis. According to Fasauyi, 2006, green vegetables are the cheapest and most abundant sources of protein because of their ability to synthesize amino acids from a wide range of available primary materials such as water, carbon dioxide, and atmospheric nitrogen. According to Nworgu, 2007, the average Nigerian consumes $7.5 \mathrm{~g}$ of animal protein per day which is low compared with the FAO average of $27 \mathrm{~g} / \mathrm{head} /$ day. To improve the above figure, the animal industry must endeavor to produce animal protein cheaply and in abundance. In this way, the majority of the citizens can afford it. One of the possible ways for solving this problem is seeking new fodders of home production and the ways of their use to provide full value feeding and to increase the productivity of poultry (Vishtakalyuk et al, 2001). Whitehead and Bannister, (1981), reported that feeding higher levels of dietary protein results in poor skin integrity and thus predispose the birds to pod dermatitis. Plants and animal feed ingredients are sources of proteins in broiler feeds and not all are favorable to broilers. Experiments have shown that soya bean meals used worldwide are the most abundant protein sources in broiler feeds and the most detrimental on feet quality, Abbott et al 1969 and Jensen, et al, 1970, especially when birds are in constant touch with their feces and as well as the availability of indigestible oligosaccharides present in soybean meal that causes sticky droppings, Boling and Firman, 1997, a condition not seen in green vegetables.

Fluted pumpkin (Telfairia occidentalis) is a leafy vegetable called Ugu in Igbo and Iroko in Yoruba (Nworgu, 2007) and Alaefo in Hausa. Amaranthus cruentus commonly called green is a highly popular vegetable crop for both rural and urban farmers and dwellers. Cabbage (Brassica oleracea var. capitata) is a vegetable food that is found in red and white varieties, and it has been consumed worldwide either raw or cooked. The researchers are of the opinion that graded levels of mixed leaves of fluted pumpkin, cabbage and green will help in reducing the escalating feed costs since they are nutritionally rich, readily available and economically cheap.

Therefore, the present study using a homogenous mix of Fluted pumpkin (Telfairia occidentalis), Green (Amaranthus cruentus) and Cabbage (Brassica oleracea var. capitata) is designed to evaluate the economic analysis, egg quality characteristics and growth performance of pullets fed graded levels of recycled vegetable wastes.

\section{Materials and Methods}

\section{The site of the experiment}

This study was conducted at the poultry unit of Imo State Polytechnic Teaching and Research Farm, Umuagwo, Ohaji Local Government Area of Imo State in the South Eastern Zone of Nigeria. The site has the coordinates of 7001 and 0611 and 70031 $0011 \mathrm{E}$ and 502810011 and $503010011 \mathrm{~N}$, with an average yearly rainfall of $172-190 \mathrm{~cm}$. Rainfall is uniformly distributed. It has a maximum temperature of $340 \mathrm{C}$ and a minimum temperature of $180 \mathrm{C}$ (Areola et al, 2002).

\section{Sample collection}

The vegetable rejects of Cabbage (Brassica oleracea var. capitata), Fluted pumpkin (Telfairia occidentalis) and Green (Amaranthus cruentus) leaves were collected from the main market refuse dump site of the Owerri Municipal Local Government Area (LGA), Owerri, Imo State, Nigeria. The rejected leaves were washed and dried in dirty free room temperature for two weeks (14 days) until crispy and then run through a hammer mill to produce a homogenous mix of Brassica oleracea var. capitata leaf meal (BOLM), Telfairia occidentalis leaf meal (TOLM), and Amaranthus cruentus Leaf Meal (ACLM), respectively. The homogenized Vegetable Meal (HVM) of BOLM, TOLM, ACLM were later subjected to standard proximate analysis using the standard methods (AOAC, 2011) to determine its content of crude protein, crude fiber, moisture, ash, ether extract and Nitrogen Free extract (NFE) as shown in table 1.

Table 1. Proximate composition of dried recycled leaves (BOLM, TOLM and ACLM)

\begin{tabular}{lc}
\hline Composition & Percentage \\
\hline Dry matter (\%) & 85.08 \\
Moisture (\%) & 7.50 \\
Crude protein (\%) & 12.75 \\
Crude fibre (\%) & 9.85 \\
Ash (\%) & 24.14 \\
Ether Extractive (\%) & 0.97 \\
NFE (\%) & 37.35 \\
Energy $(\mathrm{Kcal} / \mathrm{kg})^{1}$ & 1876 \\
\hline
\end{tabular}

${ }^{1} \mathrm{ME}(\mathrm{Kcal} / \mathrm{kg})=37 \times \% \mathrm{CP}+81,1 \times \% \mathrm{EE}+35.5 \times \%$ NFE (Pauzenga, 1985)

\section{Experimental birds and design}

Sixty (60) Shika Brown pullets of 22 week - old were used for the experiment. The sixty pullets were selected from a pool of eighty (80) pullets and were randomly assigned to five (5) treatments with twelve (12) birds per treatment in a Completely Randomized 
Design (CRD) on the basis of vigor. Each treatment group was further replicated 4 times with three (3) birds per replicate and housed in $2 \mathrm{~m} \times 3 \mathrm{~m}$ pen on a deep litter and fed water and feed ad libitum starting from 7.00 am daily for the twenty- one (21) days of the feeding trial.

\section{Experimental Diets}

Five experimental diets were prepared in a way that diet 1 (HVM1), the control, contained no treatment diets of the homogenized vegetable meal. Diet 2 (HVM2), diet 3 (HVM3), diet 4 (HVM4) and diet 5 (HVM5) contained 1.0, 1.5, 2.0 and $2.5 \%$ of the HVM, respectively. The ingredient composition of the experimental diets is shown in table 2 .

\section{Data Collection}

The initial live weight of the birds was measured at the inception of the experiment and subsequently measured on weekly basis to evaluate weight changes. The expected feed intake per day was weighed out and served between 7 am to 7: $30 \mathrm{am}$. On the next day, the leftover feed, if any, were weighed, recorded and reincorporated in the days feed. This aided in determining daily feed intake and feed conversion for each replicate. Eggs were collected twice daily, morning and evening to calculate the percentage henday egg production and for egg quality characteristics analysis. The cost of feed per kilogram of the pullet diet was calculated using the current prevailing market prices of feed ingredients. Feed intake per bird for the 21 days that the birds were on the experimental diet was used to multiply the cost of feed consumed by a bird. The mean daily weight gain per bird was calculated by dividing mean weight gain by 21 days the experiment lasted. The mean daily feed intake per bird was calculated by adding all feed consumed and dividing the product by the number of birds that ate the feed. Feed cost per kilogram was calculated using the kilogram of feed fed multiplied by feed cost. Feed conversion ratio was calculated as kilogram feed divided by kilogram of eggs laid and the hen-day-egg production was calculated by the number of eggs produced in a day divided by the number of birds alive on the day under consideration and multiplied by $100 \%$. Five eggs were selected from each treatment group on the last day of the 7th, 14th and 21 st week for egg quality analysis. The egg quality parameters measured were Haugh unit, yolk index, albumen index, shape index, shell thickness, and yolk color. The eggs were weighed after collection and the average weight of each group determined.

\section{Determination of Quality characteristics}

The Haugh unit was calculated as described by Haugh, 1937 using the following formula: the thick albumen height of the broken egg combined with the egg weight, thus: Haugh unit $=100 \times \log$ (Albumen height+7.57-1.7 x Egg weight 0.37). The yolk index is the ratio of the height to the width of the yolk. The calculation was done as described by Lee, et al 1996. The yolk color as a measurement of Yolk Quality was determined using the Roche color fan (Vuilleumier, 1969, North and Bell, 1990). The albumen index was determined by dividing the albumen height $(\mathrm{mm})$ by albumen length $(\mathrm{mm})$ plus albumen width $(\mathrm{mm})$ multiplied by 100 . The eggshells were washed, then air-dried for three days; five repeated measurements (after removing the shell membrane) in three locations of the eggs were taken at the broad and the narrow poles and at the equator of each shell to determine the shell thickness using vernier caliper. Shell thickness was designated as the arithmetic average of the five measurements. The shape index was calculated using the equation described by Anderson, et al., 2004. The width and the height of the eggs were measured with the aid of vernier calipers before the shape index was calculated.

Table 2. Composition of experimental diets $(\mathrm{Kg})$

\begin{tabular}{|c|c|c|c|c|c|}
\hline \multirow[b]{2}{*}{ Ingredients } & \multicolumn{4}{|c|}{ Treatment Diets } & \multirow[b]{2}{*}{ HVM5 } \\
\hline & HVM1 & HVM2 & HVM3 & HVM4 & \\
\hline HVM $^{1}$ & 0.0 & 1.0 & 1.5 & 2.0 & 2.5 \\
\hline Maize & 55 & 55 & 55 & 55 & 55 \\
\hline Blood Meal & 2 & 2 & 2 & 2 & 2 \\
\hline Soya Bean Meal & 8 & 8 & 8 & 8 & 8 \\
\hline Palm Kernel cake & 5.5 & 5.5 & 5.5 & 5.5 & 5.5 \\
\hline Groundnut cake & 8 & 8 & 8 & 8 & 8 \\
\hline Wheat offal & 14 & 14 & 14 & 14 & 14 \\
\hline Lysine & .25 & .25 & .25 & .25 & .25 \\
\hline Methionine & .25 & .25 & .25 & .25 & .25 \\
\hline Bone meal & 2.5 & 2.5 & 2.5 & 2.5 & 2.5 \\
\hline Limestone & 4 & 4 & 4 & 4 & 4 \\
\hline Salt & .25 & .25 & .25 & .25 & .25 \\
\hline Premix $^{2}$ & .25 & .25 & .25 & .25 & .25 \\
\hline
\end{tabular}




\begin{tabular}{|c|c|c|c|c|c|}
\hline $\begin{array}{l}\text { Total } \\
\text { Calculated analysis }\end{array}$ & 100 & 100 & 100 & 100 & 100 \\
\hline Crude protein $(\%)$ & 17.0 & 17.0 & 17.0 & 17.1 & 17.1 \\
\hline Energy (kcal/kg & 2763 & 2742 & 2731 & 2721 & 2710 \\
\hline Ether Extract (\%) & 4.01 & 3.96 & 3.93 & 3.91 & 3.88 \\
\hline Crude Fibre & 4.38 & 4.26 & 4.26 & 4.14 & 4.14 \\
\hline Lysine & 1.40 & 1.40 & 1.40 & 1.40 & 1.40 \\
\hline Methionine & 0.80 & 0.80 & 0.80 & 0.80 & 0.80 \\
\hline Calcium & 2.40 & 2.40 & 2.40 & 2.40 & 2.40 \\
\hline Available Phosphorus & 0.60 & 0.60 & 0.60 & 0.60 & 0.60 \\
\hline
\end{tabular}

${ }^{1}$ HVM of Brassica oleracea leaf meal (cabbage), Amaranthus cruentus leaf meal (green), and

Telfairia occidentalis leaf meal (Ugu).

${ }^{2}$ Vitamin /Mineral Premix: Source: Bio-organics ${ }^{\circledR}$ high potency vitamins and trace mineral premix for layers

Vitamin A: 12, 000,000 iu, Vitamin D3: 2,500,000 iu, Vitamin E: 20,0000 mg, Vitamin K3: 2,000 mg,

Vitamin B1: 2,000 mg, Vitamin. B2: 5,000 mg, Niacin: 30,000 mg, Pantothenic Acid: 11,000 mg, Vitamin.

B6: 4000mg, Vitamin B12: 15mg, Folic Acid: 1,500mg, Biotin H2: 60mg, Choline chloride: 220,000mg,

Cobalt: 200mg; Copper 3,000mg, Iron: 20,000mg, Manganese: 50,000mg, Selenium: 1,000mg, Zinc:

$40,000 \mathrm{mg}$, and Antioxidant: $1,250 \mathrm{mg}$

\section{Data analysis}

Data obtained from the response variables were subjected to a one-way analysis of variance (ANOVA), according to the procedure of Steel and Torrie (1980). The significant differences were separated using Duncan Multiple Range Test as described by Gordon and Gordon (2004).

\section{Results and Discussion}

\section{Growth indices and production performances}

The effects of recycled vegetable wastes on the growth indices and production performance of 22week-old Shika Brown pullets are shown in table 3.

\section{Hen-day egg production}

The hen-day egg production as an excellent indicator of how well the live birds are laying was not significant $(\mathrm{p}<\mathrm{0.05})$ among treatments. The percentage of hen-day-production figures are shown in tables 3 and 5 . There were no significant differences $(p>0.05)$ between the treatments.

\section{Average body weight gain (g)}

The data on average body weight gain $(\mathrm{g})$ are presented in Table 3. Birds on treatments 3, 4 and 5 recorded significantly more weight gain $(\mathrm{p}<0.05)$ than treatments 1 and 2. Differences amongst treatments 1 and 2 and treatments 3,4 and 5 were not significant ( $\mathrm{p}>0.05)$. The respective values were 142.6, 150.0, $209.4,233.0$ and $255.0 \mathrm{~g}$, respectively. The performance of treatments 3,4 and 5 did not reflect on the average feed intake of the birds as their respective values of 123,121 and121g were not significant $(\mathrm{p}>0.05)$.

\section{Average feed intake (g/bird/day)}

The average feed intake ( $\mathrm{g} / \mathrm{bird} / \mathrm{day})$ was not significant $(p>0.05)$, but the consumption rate was high for treatment 3 and low for treatment 1 . This finding was erratic and could have been due to the texture of the feed as the experimental feed was bulky and fibrous. The finding agrees with the work of Homer \& Schaibe (1980) that feed intake is influenced by the energy concentration of the feed with all parameters adequately balanced. It is worthy of note that the respective lower feed intakes in treatments 4 $(121 \mathrm{~g} / \mathrm{bird} /$ day $)$ and in treatment 5 (121/bird/day) produced more egg weight of $78 \mathrm{~g}$ and $80 \mathrm{~g}$ as well as high mean body weight gain of $233 \mathrm{~g}$ in treatment 4 and $225 \mathrm{~g}$ in treatment 5 , respectively. This may be due to the breed of the birds, the increased level of inclusion rate of HVM and also to the feed quality. The respective numerical values were $120,122,123$, 121 and $121 \mathrm{~g} / \mathrm{bird} /$ day for treatments $1,2,3$, 4, and 5, respectively.

\section{Average egg weight (g)}

The average egg weight $(\mathrm{g})$ is also shown in table 3. The result shows that treatments 4 and 5 were significantly better $(\mathrm{p}<0.05)$ than in treatments 1 to 3 . Egg grading is the sorting of products according to quality, size, weight and other factors that determine the relative value of the product (USDA, 2005). It is the grouping of eggs into lots with similar weight and quality. In Nigeria, many farmers tend to dispose of their eggs daily as they are collected from the farm, without sorting or grading of the eggs. This results in the inefficient and inappropriate pricing of eggs by the farmers with its associated economic losses and increased wastages. In all the experiments, the average egg weight ranged from $60-80 \mathrm{~g}$. These are extra-large eggs as reported by (Aduku, 1991). Considerable wastage and economic loss will occur to a farmer if these sizes are not sorted for maximum revenue returns. 


\section{Feed conversion ratio}

The feed conversion ratio (FCR) (Table 3) were significantly better $(p<0.05)$ in treatments 4 and 5 than in treatments 1 to 3 . The feed conversion is expressed as a ratio of units of feed consumed per unit of product. It is an important production parameter in commercial layer industry. Birds which were the best in feed conversion provided the greatest return on money invested. In this experiment, treatments 4 and 5 with FCR of 1.55 and 1.51 , respectively, converted feed most effectively into an egg $(\mathrm{p}<0.05)$ and, therefore, had the best returns on money invested. Ratios of $1.81,1.97$ and 2.00 were recorded for treatments 3,2 and 1 , respectively.

Table 3. Effects of recycled vegetable wastes on the growth indices and production performances of 22-week-old Shika Brown pullets

\begin{tabular}{lrrrrrr}
\hline & \multicolumn{3}{c}{ Treatment Diets } \\
Parameters & HVM1 & HVM2 & HVM3 & HVM4 & HVM5 SEM \\
\hline Protein (\%) & 17.00 & 17.00 & 17.03 & 17.07 & 17.08 & + \\
Energy (ME Kcal/kg) & 2763 & 2742 & 2731 & 2721 & 2710 & + \\
Calorie/Protein Ratio & 163 & 161 & 160 & 160 & 159 & + \\
Lysine/Methionine Ratio & 2 & 2 & 2 & 2 & 2 & + \\
Hen-day egg production (\%) & $64^{\mathrm{a}}$ & $68^{\mathrm{a}}$ & $68^{\mathrm{a}}$ & $66^{\mathrm{a}}$ & $70^{\mathrm{a}}$ & 1.02 \\
Average body weight gain (g) & $142.6^{\mathrm{a}}$ & $150.0^{\mathbf{a}}$ & $209.4^{\mathrm{b}}$ & $233.0^{\mathrm{b}}$ & $225.0^{\mathrm{b}}$ & 19.1 \\
Average egg weight (g) & $60^{\mathrm{a}}$ & $62^{\mathrm{a}}$ & $68^{\mathbf{b c}}$ & $78^{\mathbf{b}}$ & $80^{\mathbf{b}}$ & 4.07 \\
Average feed intake (g/bird/day) & $120^{\mathrm{a}}$ & $122^{\mathrm{a}}$ & $123^{\mathrm{a}}$ & $121^{\mathrm{a}}$ & $121^{\mathrm{a}}$ & 0.51 \\
FCR (kg feed/ kg egg) & $2.00^{\mathrm{a}}$ & $1.97^{\mathrm{a}}$ & $1.81^{\mathbf{b c}}$ & $1.55^{\mathbf{b}}$ & $1.51^{\mathbf{b}}$ & 0.10 \\
\hline
\end{tabular}

$\mathbf{a}, \mathbf{b}, \mathbf{c}$ Mean values within rows without a common superscript are significantly different $(\mathrm{p}<0.05)$.

+ Not subjected to statistical analysis.

SEM: Standard error mean

\section{Egg Quality Parameters}

The effects of recycled vegetable wastes on the egg quality parameters of 22-week- old Shika Brown pullets are shown in table 4. According to (Narushim, 1997), external egg quality is determined by characteristics like egg weight, shell quality, shape index, and shell thickness, while the internal egg quality characteristics are determined by Haugh unit, albumen index, yolk index, and yolk color.

\section{Height Unit}

Haugh unit measurement is an important industry measure of egg quality based on the height of its egg white (albumen); the higher the number, the better the quality of the egg. The Haugh unit in this experiment that ranges of 70.61 to 73.01 is indicative of the freshness of the eggs from the Shika brown pullets used for this experiment. The figures in this findings are lower than those reported by (Essien, 1990) and (Uchegbu, et. al 2011). The Height Unit scores for treatment 4 and treatment 5 were significantly better $(p<0.05)$ than treatments $1-3$ and so has a better quality egg.

\footnotetext{
Albumen Index

The effects of recycled vegetable wastes on the Albumen index of 22-week-old Shika Brown pullets are shown in table 4 . The differences among treatments were not significant $(\mathrm{p}>0.05)$ showing no apparent change with an increase in the inclusion rate. The recorded albumen index scores for the treatment $1,2,3,4$ and 5 were $0.07,0.08,0.08,0.08$ and 0.08 , respectively.
}

\section{Shape Index}

Egg shape index is defined as the ratio of width to length of the egg, and it is an important criterion in determining egg quality. Table 4 also shows the egg index measurements. Treatments 2-5 were significantly better $(\mathrm{p}<0.05)$ than treatment 1 . Differences between treatment 2 to 5 were not significant $(p>0.5)$. This finding tends to show a lack of positive correlation between shape index and Haugh unit and, therefore, agrees with the findings of (Kul and Seker, 2004); (Olawumi and Ogunlede, 2008) and (Zhang, et. al., 2005).

\section{Yolk Index}

Yolk index also measures the freshness of an egg. As the egg deteriorates, the yolk index decreases. The yolk index in table 4 showed that treatments $2-5$ were significantly $(\mathrm{p}<0.05)$ better than treatment 1 . Differences between treatments 2-5 were not significant $(\mathrm{p}>0.05)$. The yolk index scores range of 0.33 to 0.45 obtained this study approximates the findings of (Essien 1990 and Uchegbu et al 2011). The yolk index is the measure of the standing- up of the yolk and declines slowly with the passage of time of the storage period (Altan, et. al, 1997; Imaic, et. al, 1986 and Suk and Park, 2001). As the egg deterioration progresses, the egg index score lowers due to the loosening of the vitelline membrane fibrous structure. In this experiment, the eggs were collected twice daily, morning and evening for egg quality characteristics analysis and, therefore, storage time was short and egg quality deterioration does not apply. 


\section{Shell thickness}

The shell thickness $(\mathrm{mm})$ for all the treatments as shown in Table 4 were not significant $(\mathrm{p}>0.05)$. Treatment 5 with $2.5 \%$ inclusion rate of HVM had higher $(0.33 \mathrm{~mm})$ numerical shell thickness value. Shell thickness $(\mathrm{mm})$ values for treatments $1,2,3$ and 4 were $0.31,0.32,0.32$ and $0.32 \mathrm{~mm}$, respectively. The above findings closely approximate the findings of Mohamed and Eva (2018) for thin shells (0.28-0.30 $\mathrm{mm})$ and medium shells $(0.33-0.36 \mathrm{~mm})$. The findings did not make the perceived thick shell eggs of 0.39$0.41 \mathrm{~mm}$ category of Mohamed and Eva (2018). Eggshell weight increased in the medium eggshell category with an average egg weight of $80 \mathrm{~g}$ for treatment 5 .

\section{Yolk color}

Yolk color is an indicator of the hen's diet. If birds are fed with more yellow-orange carotenoids or natural pigments the color of their yolk color changes Beardsworth and Hernandez, 2004. Yolk color is one of the main criteria by which consumers judge the quality of eggs. In this experiment, yolk color was not significant among all treatments $(p>0.05)$. As measured using Roche Colour Fan (Vuilleumiler (1969), ratios of 7.20, 7.20, 7.30, 7.30 and 7.00 were recorded for treatments $1,2,3,4$ and 5, respectively. The findings were below the yolk colors scores of 8 , 10,12 and 14 that most European consumers prefer as reported by Beardsworth and Hernandez, 2004.

Table 4. Effects of recycled vegetable wastes on egg quality parameters of 22-week-old Shika Brown Pullets

\section{Treatment Diets}

\section{$\begin{array}{lllllll}\text { Egg Quality Parameters } & \text { HVM1 } & \text { HVM2 } & \text { HVM3 } & \text { HVM4 } & \text { HVM5 } & \text { SEM }\end{array}$}

\begin{tabular}{lrrrrrl}
\hline Haugh & $71.56^{\mathrm{a}}$ & $70.61^{\mathrm{a}}$ & $70.65^{\mathrm{a}}$ & $73.00^{\mathrm{b}}$ & $73.01^{\mathrm{b}}$ & 0.534 \\
Albumen index & $0.07^{\mathrm{a}}$ & $0.08^{\mathrm{a}}$ & $0.08^{\mathrm{a}}$ & $0.08^{\mathrm{a}}$ & $0.08^{\mathrm{a}}$ & 0.002 \\
Yolk index & $0.33^{\mathrm{a}}$ & $0.43^{\mathrm{b}}$ & $0.45^{\mathrm{b}}$ & $0.44^{\mathrm{b}}$ & $0.44^{\mathrm{b}}$ & 0.050 \\
Shape index & $70.05^{\mathrm{a}}$ & $72.40^{\mathrm{b}}$ & $71.90^{\mathrm{b}}$ & $72.90^{\mathrm{b}}$ & $72.90^{\mathrm{b}}$ & 0.529 \\
Yolk colour & $7.20^{\mathrm{a}}$ & $7.20^{\mathrm{a}}$ & $7.30^{\mathrm{a}}$ & $7.30^{\mathrm{a}}$ & $7.30^{\mathrm{a}}$ & 0.245 \\
Shell thickness (mm) & $0.31^{\mathrm{a}}$ & $0.32^{\mathrm{a}}$ & $0.32^{\mathrm{a}}$ & $0.32^{\mathrm{a}}$ & $0.33^{\mathrm{a}}$ & 0.003 \\
\hline
\end{tabular}

a, b Mean values within rows without a common superscript are significantly different $(\mathrm{p}<0.05)$.

SEM: Standard error mean

\section{Economic Analysis}

The economic analysis of the production of 22week-old Shika Brown pullets fed graded levels of recycled vegetable wastes are shown in table 5. The feed cost per $\mathrm{kg}$ bag was highest in treatment 1 . Feed cost $/ \mathrm{kg}$ bag for treatments $2,3,4$ and 5 were significant $(\mathrm{p}<0.05)$ and more economical than treatments 1 . The respective values for treatments 1 , 2, 3, 4 and 5 were N81.80, N72.60, N70.60, N70.68 and $\mathrm{N} 70.60$, respectively. Feed used $(\mathrm{kg})$ to produce a $\mathrm{kg}$ of egg were significantly better $(\mathrm{p}<0.05)$ in treatments 4 and 5 than the rest of the treatments, with the control diet numerically poorer $(2.00 \mathrm{~kg}$ fee $/ \mathrm{kg}$ egg produced). The cost of feed $/ \mathrm{kg}$ egg decreased with an increase in the inclusion rate. Treatments 2, 3, 4 and 5 were significantly less expensive $(\mathrm{p}<0.05)$ than treatment 1 . Treatments 1 and 2 were not significant ( $>>0.05)$. The respective values for treatments $1,2,3$, 4 and 5 were N83.80, N74.57, N72.31, N72.23 and N72.11, respectively. This is good for farmers because vegetable wastes are cheap compared to conventional feed ingredients. The percentage hen-day egg production for all treatments was not significant $(\mathrm{p}>0.05)$.

Table 5. Economic analysis of production of 22-week-old Shika Brown pullets fed graded levels of recycled vegetable wastes.

\begin{tabular}{lcccccc}
\hline \multirow{2}{*}{ Parameters } & \multicolumn{5}{c}{ Treatment Diets } \\
\hline & HVM1 & HVM2 & HVM3 & HVM4 & HVM5 & SEM \\
Feed cost/25kg bag ( $\#)^{\mathrm{x}}$ & $2045^{\mathrm{a}}$ & $1815^{\mathrm{b}}$ & $1765^{\mathrm{b}}$ & $1767^{\mathrm{b}}$ & $1765^{\mathrm{b}}$ & 54.23 \\
Feed cost/kg bag ( $)$ & $81.80^{\mathrm{a}}$ & $72.60^{\mathrm{a}}$ & $70.60^{\mathrm{b}}$ & $70.68^{\mathrm{b}}$ & $70.60^{\mathrm{b}}$ & 2.17 \\
Kg feed / kg egg produced ( $)$ & $2.00^{\mathrm{a}}$ & $1.97^{\mathrm{a}}$ & $1.81^{\mathrm{bc}}$ & $1.55^{\mathrm{b}}$ & $1.51^{\mathrm{b}}$ & 0.10 \\
Cost of feed / kg egg ( $/ \mathrm{kg})$ & $83.80^{\mathrm{a}}$ & $74.57^{\mathrm{ab}}$ & $72.31^{\mathrm{b}}$ & $72.23^{\mathrm{b}}$ & $72.11^{\mathrm{b}}$ & 2.25 \\
Hen-day-egg production $(\%)$ & $64.00^{\mathrm{a}}$ & $68.00^{\mathrm{a}}$ & $68.00^{\mathrm{a}}$ & $66.00^{\mathrm{a}}$ & $70.00^{\mathrm{a}}$ & 1.02 \\
\hline
\end{tabular}

$\mathbf{a}, \mathbf{b}, \mathbf{c}$ Mean values within rows without a common superscript are significantly different $(\mathrm{p}<0.05)$

+ Not subjected to statistical analysis.

SEM: Standard error mean

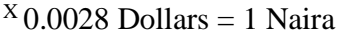




\section{References}

Abbott, W. W., Couch, J. R. and Atkinson, R. L., (1969). The incidence of foot-pad dermatitis in young turkey fed high levels of soybean meal. Poult. Sci.48:2186-2188.

Aduku, J. O., (1991). Animal products handling and processing in the tropics, Living Book Series Publication, Abuja FCT, Nigeria

Altan, Ö., Akbas, Y., Sevgican, F. and Erkek, R., (1997). Effect of cold storage on egg quality. Turk. J. Vet. Anim. Sci., 21: 335-339.

Anderson, K.E., Tharrington, J.B., Curtis, P.A. and Jones, F.T., (2004). Shell characteristics of eggs from historic strains of single comb white leghorn chickens and the relationship of egg shape to shell strength. Int, J. Poult. Sci., 3:17-19.

AOAC., (2011). Association of Official Methods of Analysis. Revised Edition, Washington D.C., USA

Areola, O, Ahmed, K, Irueghe, O.I, Adeleke, B.O., and Leong, G.C., (2002). Certificate physical and human geography for senior secondary schools. New Impression. University Press PLC, Ibadan

Beardsworth, P.M., Hernandez, J.M., (2004). Yolk Colour - An Important Egg quality attribute. Int. Poult. Prod. 12, 17-18.

Boling, S. D., Firman, J. D., (1997). Rendered byproducts as soybean meal replacement in turkey rations. J. Appl. Poult. Res.6:210-215.

D' Mello, J. P. E., Acamovic, T., and Walker, A. G., (1987). Evaluation of Leucaena leaf meal for broiler growth and pigmentation. Trop. Agri. (Trinidad), 64: $33-35$.

D'Mello, J. P. F., Acamovic, T., (1989). Leucaena leucocephala in poultry nutrition-a review. Animal Feed Science and Technology, 26: 1-28.

Ebenebe, C. I.; Itefue, O.; Ebere-Ohameje, T. C., and Okonkwo, J. C., (2011). Fortification of the nutritive value of mushroom (Termitomyces microcarpus) with paw-paw leaf meal for broiler chick's diet. Pakistan J. Nutr., 10 (2): 155-158

Esonu, B.O., Ihekwumere, F.C., Emenalom, O.O., Uchegbu, M.C., and Etuk, E.B., (2002). Performance and Nutrient Utilization and Organ Characteristic of Broilers Fed Microdesmis puberula leaf meal. Livestock Research for Rural Development 14(16) 146. www.cipar.org.collirrd.

Essien, A. I., (1990). Egg quality traits and their relationships as affected by storage method and duration of storage in the humid wet climate. Beitr. Trop. Landwitsch. Vet. Med. 28 H3: 345-353.

Fasuyi, A.O., (2006). Nutritional potentials of some tropical vegetable leaf meals: chemical characterization and functional properties. Afr. J. Biotech., 5: 49-53.

Gordon, S.P and Gordon, F.S., (2004). Contemporary Statistics. A Computer Approach. MC.Graw Hill Publishers, USA. p.695
Haugh, R. R., (1937). The Haugh unit for measuring egg quality. US Egg. Poult. Mag. 43, $572-573$

Homer, P., and Schaible, P.J., (1980). Poultry feeds and nutrition, 2nd Ed. Avian Publishing Co. Inc., WestPoint, Connecticut.

Imai, C., Mowlah, A., and Saito, J., (1986). Storage stability of Japanese quail (Coturnix coturnix japonica) eggs of room temperature. Poult. Sci., 65: 474-480.

Jensen, L. S., Martinson, R., and Schumaier, G., (1970). A foot pad dermatitis in turkey poults associated with soybean meal. Poult. Sci.49:76 82.

Kul, S., and Seker, I., (2004). Phenotypic correlations between some external and internal egg quality traits in the Japanese Quail (Coturnix coturnix japonica). International Journal of Poultry Science 3(6), 400-405.

Lee, S.H., No, H.K., and Jeong, Y.H., (1996). Effect of chitosan coating on quality of egg during storage. J. Korean Soc. Food Nutr., 25: 288-293

Mnereole, F., (2009). Evaluation of dietary inclusion of sweet potato (Ipoma batatas) leaf meal (SPLM) with and without enzyme treatment in broiler diets. Pakistan J. Nutr., 8(6): 841-844

Mohamed, K., and Eva, T., (2018). The relationship between eggshell thickness and other eggshell measurements in eggs from litter and cages. Italian J. Ani. Sci. 17(1): 234-239

Narushin, V.G., (1997). The avian egg: geometrical description and calculation of parameters. Journal of Agricultural Engineering Research 68, 201-205.

North, M.O., and Bell, D.D. (1990). Commercial chicken production manual, 4th edn. Springer, U.K.

Nworgu, F.C., (2007). Economic importance and growth rate of broiler chickens served fluted (Telfaria occidentalis) leaves extract. African J. of Biotech., 6(2): 167-174.

Nworgu, F.C. and Egbumike, G., (2000). Performance and Nitrogen Utilization of Broiler Chicks Fed Fat Extruded Soya-bean Meal and Full Fat Soybean Meal. Tropical Amon. Prod. Invest Journal 3: 47-54.

Nworgu, F.C., Ogungbenro, S.A., and Solesi, K.S., (2007). Performance and Some Blood Chemistry Indices of Broiler Chicken Served Fluted Pumpkin (Telferia occidentalis) Leaves Extract Supplement. American - European Journal of Agric and Environ. Sci., 2(1) 90-98.

Odunsi, A. A., Farinu, G. O., Akinola, J. O., and Togun, V. A., (1999). Growth, carcass characteristics and body composition of broiler chicken fed wild sunflower (Tithonia diversifolia) forage meal. Tropical Animal Production Investigation, 2: 205-211 
Ogbuokiri, U. D. E., (2011). Effect of total replacement of maize with cassava and cassava products on the skin pigmentation of broiler chickens. Animal Production Research Advances, 8(1): 20 - 24.

Ogbuokiri, U.D.E., 2012. Effect of total replacement of maize with cassava and cassava production on the skin pigmentation of broiler chickens. Animal Production Research Advances, 8(1): 20-24.

Ogbuokiri, U.D.E., Iheanacho, A.L., Osuji, A.L., Okoli, I.C., and Ekenyem, B.U., (2014). Effect of pawpaw leaf (Carica papaya, Linn.) meal on some performance attributes of starter broiler chicks. J. Anim. Sci. Adv., 4(5): 826-832.

Olawumi, S.O., and Ogunlade, J.T., (2008). Phenotypic correlation between some external and internal egg quality traits in the exotic ISA brown layer breeders, Asian Journal of Poultry Science 2(1), 30-35

Omenka, R.O., and Anyasor, G.N., (2010). Vegetable-based feed formulation on poultry meat quality. Afr. J. Food Agric. Nut. \& Dev., 10(1): 2001-2011.

Pauzenga, U., (1985). Feeding parent stock. Zootecnica International, 14: 22-24.

Steel, S. O. C., and Torrie, J.H., (1980). Principal and Procedures of Statistics. McGraw Hill Co. Inc. New York.

Suk, Y.O., and Park, C., (2001). Effect of breed and age of hens on the yolk to albumen ratio in two different genetic stocks. Poult. Sci., 80: 855-858.

Teguia, A., (1995). Substituting mango kernels (Mangifera indica $L$ ) for maize in broiler starter diets. Ani. Feed Sci. Tech. 56: 155-158.

Teguia. A., Tchoumboue, J., Mayaka, B. T., and Tankou, C. M., (1993). The growth of broiler chickens as affected by the replacement of graded levels of maize by sweet potato leaves (Ipomoea batatas) or Ndole (Vernonia spp) in the finisher diet. Ani. Feed Sci. Tech. 40: 233-237.

Teguia, A., Awah-Ndukum, J., and Puene, C., (2002a). The effects of replacing maize with dried leaves of Desmodium spp on the growth performance of broiler chickens. Bulletin of Ani. Health and Prod. in Africa 50:106-114

Teguia, A., and Beynen, A. C., (2004). Nutritional aspect of broiler production in small-holder farms in Cameroon. Livestock Res. for Rural Dev., 16 (1) 2004 http://www.cipav.org.co//rrd//rrd16/1/tegu161.ht $\mathrm{m}$

Teguia, A., Endeley, H. N. L., and Beynen, A. C., (2004). Broiler performance upon dietary substitution of cocoa husks for maize. Inter. J. Poult. Sci. 3 (12): 779-782.

Uchegbu, M. C., Herbert, U., Ogbuewu, I. P., Nwaodu, C. H., Esonu, B. O., and Udedibie, A. B. I., (2011). Performance and egg quality characteristics of layers fed diets containing combinations of brewers dried grains, jack bean, and cassava root meal. Revista Científica UDO Agrícola 11 (1): 155-160.

USDA., (2005). United States Department of Agriculture, Food Safety and Inspection Services

Vishtakalyuk, A.B., Khirug, S.S., Ezhkova, M.S., Lapin, A. A., Lisovi, and V.F., (2001). Amaranth Vitamin -Herbal Flour Ration in Feeding Hens: perspectives of their increased Egg-Laying productivity. Chemistry and Computational Simnlats, Britherow Communication, 2(5) K. Marx St, 68. 420015 Kazan, Tatarstan, Russia.

Vuilleumier, J.P. (1969). The "Roche yolk color fan" - An instrument for measuring yolk color. Poult. Sci., 48: 767- 779.

Whitehead, C. C., and Bannister, D.W., (1981). Aspects of metabolism related to the occurrence of skin lesions in biotin-deficient chicks. Br. Poult. Sci.,22: 467-472.

Zhang, L.C., Ning, Z.H., Xu, G.Y., Hou, Z.C., and Yang, N., (2005). Heritability and genetic and phenotypic correlations of egg quality traits in brown-egg dwarf layers. Poult. Sci., 84: 12091213. 